\title{
Rhizobacteriome: Promising Candidate for Conferring Drought Tolerance in Crops
}

\author{
Vinod Kumar Yadav ${ }^{1,2}$, Meenu Raghav², Sushil K. Sharma ${ }^{1,3 *}$ (D) and \\ Neeta Bhagat ${ }^{2 *}$ (D)
}

${ }^{1}$ ICAR-National Bureau of Agriculturally Important Microorganisms (ICAR-NBAIM), Kushmaur, Maunath Bhanjan - 275 103, Uttar Pradesh, India. ${ }^{2}$ Amity Institute of Biotechnology, Amity University, Sector 125, Noida - 201 301, Uttar Pradesh, India. ${ }^{3}$ Present Address -ICAR-National Institute of Biotic Stress Management (ICARNIBSM), Baronda, Raipur - 493 225, Chhattisgarh, India.

\begin{abstract}
Drought is a global water shortage problem which poses challenge to crop productivity. Novel strategies are being tried to find out solution to sustain agriculture under drought conditions. Rhizobacteriome is an exclusive genetic material of bacteria resident to rhizosphere plays critical role to health and yield of plant. The interaction of rhizobacteriome with plant provides basis for protecting plants from various abiotic and biotic stresses. Plant growth promoting rhizobacteria (PGPR) are root-colonizing bacteria which produce array of enzymes and metabolites that assist plants to withstand harsh environmental conditions. Various formulations of rhizobacteria are being applied to enhance the tolerance or endurance to drought in crops which in turn increase crop productivity. This could be a one of the promising methods with wide potentiality to improve the growth and yield of crops under limited water resources and changing climatic conditions to ensure food security of the globe. In this review, we summarize (1) existing knowledge and understanding about the rhizobacteria, (2) their role in imparting tolerance to crops in drought conditions and (3) discuss future line of work in this frontier research area.

Keywords: Rhizobacteriome, bacteria- plant interactions, rhizosphere, drought stress, ACC deaminase, rhizobacteria
\end{abstract}

*Correspondence: nbhagat@amity.edu; sks_micro@rediffmail.com

(Received: August 14, 2019; accepted: January 14, 2020)

Citation: Vinod Kumar Yadav, Meenu Raghav, Sushil K. Sharma and Neeta Bhagat, Rhizobacteriome: Promising Candidate for Conferring Drought Tolerance in Crops, J. Pure Appl. Microbiol., 2020; 14(1): 73-92. https://doi.org/10.22207/JPAM.14.1.10

(C) The Author(s) 2020. Open Access. This article is distributed under the terms of the Creative Commons Attribution 4.0 International License which permits unrestricted use, sharing, distribution, and reproduction in any medium, provided you give appropriate credit to the original author(s) and the source, provide a link to the Creative Commons license, and indicate if changes were made. 


\section{INTRODUCTION}

Drought stress has increased tremendously in last few years affecting food security at global level. The drought stress duration is ranged as short, severe, extremely severe and prolonged that adversely affects the agricultural productivity ${ }^{1}$. Drought is the most destructive abiotic stress which may affect crops of $50 \%$ of the arable lands by $2050^{2}$. It is a serious issue in the context of agricultural sector as it reduces crop yield in regions with scanty rainfall in various parts of the world ${ }^{3}$. Presently, various effective practices like efficient water irrigation techniques, conventional and modern plant breeding methods, and production of drought-tolerant transgenic plants through genetic engineering can be adopted to address the problem of sustainable crop production in drought situations. However, such techniques or procedures or methods need sophisticated technical knowhow and are costly and labor intensive as they are arduous to implement. An alternative method for promoting plant growth under drought conditions is to manipulate plant growth promoting rhizobacteria (PGPR) that are found in the rhizosphere and endorhizosphere in plant root systems. PGPR induces plant growth by various direct or indirect mechanisms under normal, biotic or abiotic stress conditions ${ }^{4}$. Rhizosphere is the area where, interaction among soil, plants and microorganisms take place. The microorganisms present in the rhizosphere, compete for their survival. This competition is for the need of nutrients, water and space to develop their association with plant. The plantmicrobes interactions lead to the improvement in growth and development of plants ${ }^{5}$. Diverse bacterial genera form the important component of soils facilitating various biotic activities like recycling nutrient of the soil ecosystem which is essential for sustainable crop yield ${ }^{6,7}$. PGPR mobilize different nutritive components in soil, produce plant growth regulators and inhibit phytopathogens ${ }^{8}$. They also improve quality of soil by bioremediation of the pollutants by facilitating uptake of heavy toxic metal and degradation of xenobiotic compounds including pesticides ${ }^{9,10}$. Agronomists and environmentalists adapting various biological methods for integrated plant nutrient management system ${ }^{11}$. Rigorous research has been undertaken globally on exploring rhizobacteria possessing novel characteristics like ability to detoxify heavy metals ${ }^{12}$, salinity tolerance ${ }^{13}$, biological control of phytopathogens and insects ${ }^{14}$ along with the plant growth promoting properties like, phytohormones production ${ }^{15,16}$ phosphate solubilization ${ }^{17}, 1$-aminocyclopropane1-carboxylate ${ }^{18}$, hydrogen cyanide (HCN), and ammonia production ${ }^{19}$ nitrogenase activity $^{20}$, siderophore ${ }^{21}$ production. Hence, diverse groups of symbiotic bacteria like Bradyrhizobium, Rhizobium, Mesorhizobium and non-symbiotic like Bacillus, Klebsiella, Pseudomonas, Azotobacter, Azomonas, Azospirillum have been used worldwide as biofertilizer for promoting growth and development of plants under abiotic stress ${ }^{22,7}$. Although no single mechanism of rhizobacteria -mediated plant growth promotion is completely understood, however PGPR show significant contribution to the improvement in crop production ${ }^{23}$.The potential of inoculated bacteria to survive, multiply to outnumber the native bacteria and other microflora, and colonize the rhizosphere is crucial for its successful application ${ }^{22}$ specifically in drought-affected soils. The bacteria that are not adapted to drought conditions will die out under these unfavorable growth conditions ${ }^{24,25}$. But, the drought-tolerant rhizobacteria are capable of thriving in new drought stressed soil in sufficient number to show plant growth promoting manifestations on plants ${ }^{26,27}$. The present review highlights past and current status of role of rhizobacteriome on plant growth promotion under drought conditions. Further, it will also emphasize mechanisms associated with in conferring drought tolerance in crops on application of rhizobacteria.

\section{Rhizosphere and rhizobacteriome}

The term "rhizosphere" was first used by Hiltne ${ }^{27}$. Rhizosphere is multidimensional and dynamic region around root where significant plant-microbe interactions occur ${ }^{28}$. The root exudates alter the physicochemical properties of soil, which directly effects the multiplication of soil microorganisms ${ }^{29}$. These root exudates have ability to attract or repel microorganisms and promote symbiotic interactions which help in growth and development of plant ${ }^{30}$. PGPR are characterized by their capability to colonize the plant root surface, multiply, compete and survive to promote plant 
growth $^{31}$. PGPR are broadly categorized into two classes: 1) ePGPR (extracellular PGPR) which grow in the rhizospheric area or in between cells of root cortex, examples include Agrobacterium, Azotobacter, Erwinia, Serratia, Bacillus etc. 2) iPGPR (intracellular PGPR) which grow inside root cells, examples include Azorhizobium, Mesorhizobium, Allorhizobium etc ${ }^{24}$. The entire set of genetic material of the root associated bacteria is called "rhizobacteriome".

The rhizosphere is hot spot for number of organisms which represent most complicated and dynamic ecosystems on the Earth ${ }^{32,33}$. Rhizosphere organisms consist of arthropods, archaea, viruses, algae, protozoa, nematodes, oomycetes, fungi and bacteria ${ }^{34}$. The rhizosphere examplifies complicated food web which utilise various nutrients produced by plants. Rhizosphere is identified by presence of exudates, border cells, mucilage called as rhizodeposits. Rhizodeposits represent diverse microbial community and microbial activity on plant roots ${ }^{35}$. However, the organisms of rhizosphere are analysed for their beneficial impact on growth and development of plants including nitrogen fixing bacteria, protozoa, mycoparasitic fungi, biocontrol microorganisms, fungi and plant growth promoting bacteria (PGPR)/ rhizobacteria. Some of organisms present in rhizosphere like nematodes, bacteria, oomycetes and pathogenic fungi, have adverse effects on growth of plants. Some human pathogens are also found in the rhizosphere ${ }^{36}$. Abiotic stresses have various impacts on rhizospheric bacteria. Total bacterial biomass decline under drought situation $\mathrm{s}^{37}$ resource limitation but stable biomass has been observed in certain cases of soil bacteria in drought condition ${ }^{31}$ as repeated drought exposures make; bacteria to learn to survive ${ }^{38}$.

Drought forces shift microbial composition in drought affected soil ${ }^{39}$. An increased ratio of Gram-positive to Gramnegative bacteria has been observed during water stressed conditions ${ }^{40}$. Drought affected soil decreases members of Gram-negative phyla like Proteobacteria, Verrucomicrobia, and Bacteroidetes and increases members of Gram-positive phyla like Actinobacteria and Firmicutes ${ }^{41,42}$. Also, the total numbers of genes of microbes present in the drought striken rhizosphere are exceeding the numbers of genes in plant in that area. Variation in metatranscriptome and metagenomics profiling of microbial genes related to metabolism, signal transduction and other vital activities of dry and well aerated soil suggests that microbial genes might contribute to plant survival and drought tolerance ${ }^{43}$. Some important

Table 1. Role of bacterial IAA on plant growth under drought stress condition

\begin{tabular}{|c|c|c|c|c|c|}
\hline S.No. & PGPR & Plant & Impact on plant & Reference & Year \\
\hline \multirow[t]{2}{*}{1.} & Azospirillum brasilense & & & & \\
\hline & & Tomato & $\begin{array}{l}\text { Nitric oxide a signaling } \\
\text { molecules and IAA pathway } \\
\text { for induction of lateral and } \\
\text { root hair growth }\end{array}$ & $\begin{array}{l}\text { Molina-Favero } \\
\text { et } a .^{52}\end{array}$ & 2008 \\
\hline 2. & Azospirillum sp. & Wheat & $\begin{array}{l}\text { Enhanced lateral roots, root } \\
\text { growth, increased water and } \\
\text { nutrient uptake }\end{array}$ & $\begin{array}{l}\text { Arzanesh } \\
\text { et al. }{ }^{51}\end{array}$ & 2011 \\
\hline 3. & $\begin{array}{l}\text { Pseudomonas putida, } \\
\text { Bacillus megaterium }\end{array}$ & $\begin{array}{l}\text { Trifolium } \\
\text { repens }\end{array}$ & $\begin{array}{l}\text { Increased shoot } \\
\text { and root mass }\end{array}$ & $\begin{array}{l}\text { Marulanda } \\
\text { et al. }{ }^{.7}\end{array}$ & 2009 \\
\hline 4. & B. thuringiensis & $\begin{array}{l}\text { Lavandula } \\
\text { dentate }\end{array}$ & $\begin{array}{l}\text { Increased levels of K-and } \\
\text { proline, decresed glutathione } \\
\text { reductase (GR) and ascorbate } \\
\text { peroxidase (APX) }\end{array}$ & $\begin{array}{l}\text { Armada } \\
\text { et al. }{ }^{55}\end{array}$ & 2014 \\
\hline 5. & $\begin{array}{l}\text { Rhizobium phaseoli (MR-2) } \\
\text { Mesorhizobium ciceri (CR-30 } \\
\text { and CR-39) and Rhizobium } \\
\text { phaseoli (MR-2) }\end{array}$ & Wheat & $\begin{array}{l}\text { IAA from consortia } \\
\text { improved growth, biomass } \\
\text { and drought tolerance index }\end{array}$ & $\begin{array}{l}\text { Hussain } \\
\text { et al. }{ }^{56}\end{array}$ & 2014 \\
\hline
\end{tabular}


members of rhizobacteriome are Acinetobacter, Achromobacter, Agrobacterium, Alcaligenes, Arthrobacter, Azotobacter, Azospirillum, Bacillus, Bradyrhizobium, Burkholderia, Enterobacter, Erwinia, Flavobacterium, Gluconacetobacter, Herbaspirillum, Klebsiella, Leclercia, Micrococcus, Paenibacillus, Phyllobacterium, Proteus, Pseudomonas, Raoultella, Rhizobium, Rhodococcus, Serratia, Variovorax and Xanthomonas ${ }^{24}$. These rhizospheric bacteria show profound impact on germination of seed, plant growth, seedling vigor, development, diseases, nutrition and productivity $^{44}$.

PGPR and their drought tolerance mechanisms

PGPR induce tolerance to drought stress in crops by production of phytohormones, producing volatile compounds, ACC deaminase, osmolyte and exopolysaccharides, and triggering antioxidant activities.

Role of rhizobacterial phytohormones in drought stress tolerance

In drought stress, there is reduced production of phytohormones which inhibit normal plant growth. PGPR are capable for producing phytohormones that help to sustain growth and division of plant cell under abiotic environmental stress ${ }^{45}$. Phytohormones like indole -3-acetic acid (IAA), gibberellin (GA), cytokinin, abscisic acid and ethylene produced by rhizobacteriome become significant for promoting growth and development and helping plants to escape abiotic stress ${ }^{46,47}$. These pose as important targets for engineering metabolic products for conferring drought tolerance to crop plants ${ }^{48}$.

Inoculation with various IAA producing bacteria enhanced lateral roots and roots hairs formation along with overall root growth, thus effecting increased water and nutrient uptake in drought conditions ${ }^{49,50}$. For example, IAA produced by Azospirillum increased plant ability to tolerate drought stress in maize and wheat ${ }^{51}$, and by nitric oxide production in tomato ${ }^{52}$. The simultaneous production of siderophores and auxins by Streptomyces increases the plant growth-promoting effects of auxins, which in turn enhances the phytoremediation potential of plants ${ }^{53}$. A. brasilense Sp245 applied in wheat (Triticum aestivum) improved crop yield, micronutrients content, water content, water potential thus increased drought tolerance in plants $^{54}$. A.brasilense also triggers nitric oxide signaling in IAA pathway and thereby improved growth of lateral root and root hair in tomato under drought stress ${ }^{52}$. B.thuringiensis improved nutritive value, physiological activities and metabolic activities of Lavandula dentate through IAA produced by the bacteria ${ }^{54,55}$. IAA signaling by consortium of Rhizobium leguminosarum (LR30), Mesorhizobium ciceri (CR-30 and CR-39), and Rhizobium phaseoli (MR-2) inoculated in wheat improved crop $^{56}$. Inoculation of Pseudomonas putida, Pseudomonas sp. and Bacillus megaterium increased water content and shoot / root biomass in Trifolium repens under water stressed conditions $^{57}$ (Table 1). Bacillus subtilis, B. cereus, Enterobacter cloacae, Pseudomonas koreensis, and $P$. fluorescens promoted seed germination by IAA production and phosphate solubilization under drought like condition induced by different concentrations of polyethylene glycol (PEG 6000) ) $^{58}$.

The capability of gibberellin producing bacteria to stimulate plant growth has also been well documented as it plays prominent role in various physiological processes. For example gibberellin produced by bacterial strains $B$. macroides $\mathrm{CJ}-29, B$. cereus $\mathrm{MJ}-1$, and $B$. pumilus

Table 2. Role of rhizobacterial gibberellin on plant growth under drought stress condition

\begin{tabular}{|c|c|c|c|c|c|}
\hline S.No. & PGPR & Plant & Impact on plant & Reference & Year \\
\hline 1 & P. putida $\mathrm{H}-2-3$ & Soybean & $\begin{array}{l}\text { Improved plant growth } \\
\text { using gibberellins }\end{array}$ & Sang-SM et al. ${ }^{60}$ & $2014 b$ \\
\hline 2. & $\begin{array}{l}\text { Azospirillum } \\
\text { lipoferum }\end{array}$ & Maize & $\begin{array}{l}\text { Gibberellins increased } \\
\text { ABA levels and } \\
\text { alleviated drought stress }\end{array}$ & Cohen et al. ${ }^{50}$ & 2009 \\
\hline 3. & $\begin{array}{l}\text { B. cereus } \mathrm{MJ}-1 \text {, } \\
\text { B. macroides CJ-29, } \\
\text { and B. pumilus CJ- } 69\end{array}$ & Pepper & Increased GA & Joo et al. ${ }^{59}$ & 2005 \\
\hline
\end{tabular}


$\mathrm{CJ}$ enhanced the growth of red pepper plants ${ }^{59}$. Similarly, gibberrelin producing $P$. putida $\mathrm{H}-2-3$, a increased growth of soybean plants in drought ${ }^{60}$ (Table 2). Azospirillum lipoferum supported in mitigating activity of stress created by drought in plants of maize via yielding of $A B A$ and gibberellin ${ }^{50}$.

Under water deficit situation, biosynthesis of stress hormone i.e. ABA is triggered by dehydration conditions $s^{61}$. The involvement of $A B A$ has been observed in regulating water loss through controlling the closing of stomata and transduction pathways of stress signals ${ }^{62}$. Arabidopsis plants showed elevated levels of $A B A$ when inoculated with $A$. brasilense sp245 $25^{50}$. Phyllobacterium brassicacearum strain STM196 isolated from the rhizosphere of Brassica napus, elevated ABA content leading to decreased leaf transpiration and enhanced osmotic stress tolerance in Arabidopsis plants ${ }^{63}$. Cytokinin producing Bacillus subtilis enhanced $A B A$ in shoots and increased the stomatal conductance conferring drought stress resistance in Platycladus orientalis seedlings ${ }^{64}$ (Table 3).

Cytokinin producing bacterial strains like Pseudomonas E2, Bacillus licheniformis Am2 and Bacillus subtilis BC1 reported to enhance cotyledon growth in cucumber ${ }^{65}$. Inoculation of lettuce with cytokinin producing bacteria increased shoot cytokinins and also promoted the accumulation of shoot mass and shortened roots $^{66}$. Cytokinin producing $B$. subtilis strain IB21 stimulate rhizodeposition for rhizobacterial colonization in the wheat rhizosphere ${ }^{67,68}$ (Table 4). ACC deaminase production by rhizobacteria

Ethylene, a ubiquitous hormone in plants, plays role in seed germination, leaf abscission, ripening of fruits, senescence of leaf, initiation and elongation of roots, rhizobia nodule formation etc. ${ }^{69,70}$. In drought stress, synthesis of ethylene increase by conversion of S-adenosylmethionine (SAM) into 1-aminocylcopropene-1-carboxylase (ACC), the precursor of ethylene, in presence of ACC synthase ${ }^{71}$. PGPR act as sink of ACC by controlling ethylene formation using the ACC (1-aminocyclopropane-1-carboxylate) deaminase enzyme. These PGPR hydrolyse the ACC into ammonia and $\alpha$-ketobutyrate, and thereby stimulate the expulsion of ACC from the roots to the soil ${ }^{72}$. Decreased ACC concentration in root further decreases the formation of endogenous ethylene preventing retardation in plant growth. Reducing ethylene-mediated inhibitory effects on plant growth and facilitate enhanced plant resistance to drought. Achromobacter picchaudii ARU8 secretes ACC deaminase that degrades ACC to ammonia for nitrogen and energy supply and thus decreases ethylene production under water deficit condition ${ }^{73,74}$. Pseudomonas fluorescens, Enterobacter hormaechei, and Pseudomonas migulae are three ACC and EPS producing microbes which when inoculated in foxtail millet could promote seedling germination in drought condition ${ }^{75}$. PGPR possessing ACC deaminase activity reduce toxicity of heavy metals, drought stress and other abiotic stresses like extreme temperature, salinity and soil $\mathrm{pH}$, besides, antagonism against phytopathogens ${ }^{76}$. Dodd et al. (2005) ${ }^{77}$ studied effect of ACC deaminase producing Variovorax paradoxus $5 \mathrm{C}-2$ on pea plant physiological (Pisum sativum L.) in water conditions. Consortium of Ochrobactrum. pseudogrignonense RJ12, Pseudomonas sp. RJ15, and B. subtilis RJ46 showed mitigation of drought

Table 3. Role of rhizobacterial bacterial abscisic acid on plant growth under drought stress condition

\begin{tabular}{|c|c|c|c|c|c|}
\hline S.No. & PGPR & Plant & Impact on plant & Reference & Year \\
\hline 1. & Bacillus subtilis & $\begin{array}{l}\text { Platycladus } \\
\text { orientalis }\end{array}$ & $\begin{array}{l}\text { Increased shoot ABA levels } \\
\text { and increased the stomatal } \\
\text { conductance }\end{array}$ & Liu et al. ${ }^{64}$ & 2013 \\
\hline 2. & $\begin{array}{l}\text { Phyllobacterium } \\
\text { brassicacearum } \\
\text { STM } 196\end{array}$ & $\begin{array}{l}\text { Arabidopsis } \\
\text { thaliana }\end{array}$ & $\begin{array}{l}\text { Reduced leaf transpiration } \\
\text { due to increase level of } \\
\text { ABA }\end{array}$ & Arzanesh et $a l^{51}$ & 2013 \\
\hline 3. & $\begin{array}{l}\text { Azospirillum } \\
\text { lipoferum }\end{array}$ & Maize & $\begin{array}{l}\text { Increased gibberellins and } \\
\text { ABA levels }\end{array}$ & Cohen et al..$^{50}$ & 2009 \\
\hline
\end{tabular}


stress in garden pea and black gram plants ${ }^{73}$. Leclercia adecarboxylata and Agrobacterium fabrum, Bacillus amyloliquifaciens with higher ACC-deaminase and IAA production traits elevated nutrients uptake and high chlorophyll contents ${ }^{78,79}$. Pseudomonas fluorescens DR7 having high ACC deaminase- and EPS-producing ability increased moisture content in soil and enhanced the root adhering soil and root growth in foxtail millet ${ }^{80}$. Pot trials experiment showed that inoculation with ACC deaminase-producing bacterial strains of Pseudomonas (DPB13, DPB15, and DPB16) conferred vital improvement in growth of wheat plant in drought-stressed conditions ${ }^{81,82}$. Similarly, Bacillus lecheniformis K11 protected pepper and Bacillus, Psuedomonas and Mesorhizobium ciceri protected chickpea in drought stress ${ }^{83,84,85}$ (Table 5).

Volatile organic compounds (VOCs) producing rhizobacteria and drought stress tolerance

Under stress condition, plants produce volatiles which act as signal for development of systemic response or for priming within the plant or in neighboring plants. VOCs that are produced by diverse group of bacteria Pseudomonas, Bacillus, Arthrobacter, Stenotrophomonas, and Serratia increase growth of plants, inhibit fungal and bacterial pathogens and nematodes along with inducing systematic resistance in plants towards phytopathogens ${ }^{86}$. Various VOCs produced by different species of microorganisms in soil include 11-decyldocosane, dotriacontane, 2,6,10-trimethyl, tetradecane, 1-chlorooctadecane, dodecane, benzene(1methylnonadecyl),1-(N-phenylcarbamyl)-2- morpholinocyclohexene, decane, methyl, benzene, 2-(benzyloxy) ethanamine and cyclohexane ${ }^{87}$.

Gram-positive Bacillus spp. (GB03 and IN937a) and Gram-negative E. cloacae strain JM22 elicited growth promotion of Arabidopsis seedlings through VOCs production ${ }^{88}$. Inoculated with $P$. chlororaphis $\mathrm{O} 6$ or exposed to 2,3-butanediol increased process of stomata closure and hence reduced loss of water in Arabidopsis plants thereby enhanced drought tolerance ${ }^{89}$. High rate of photosynthesis correlated with reduced VOCs production, enhanced survival under drought stress in plants primed with Bacillus thuringiensis AZP2. This proved that inoculation with bacterial improved drought stress tolerance ${ }^{90}$ (Table 6).

\section{Exopolysaccarides (EPS) producing rhizobacteria and drought tolerance}

Many bacteria like Pseudomonas are capable of surviving in drought conditions due to development of exopolysaccharides (EPS). Pseudomonas sp. P45 produces EPS and protects sunflower plant from stress created by drought condition $^{91}$. EPS consist of high molecular weight polymer of monosaccharide residues and their derivatives. These are biodegradable polymers biosynthesized by various algae, plants and bacteria $^{91}$. Microbes produce EPS in capsular form and release it into the soil, the clay surface absorbs the EPS by Van der Waals force, hydrogen bonding, cation bridges or anionic absorption ${ }^{92}$. This protective capsule provides soil, the capacity of holding water and drying water more slowly under drought condition ${ }^{93}$ and nutrients uptake by increasing the water potential around roots. Inoculating with EPS and catalase producing

Table 4. Role of cytokinin producing rhizobacteria on plant growth under drought stress condition

\begin{tabular}{|c|c|c|c|c|c|}
\hline S.No. & PGPR & Plant & Impact on plant & Reference & Year \\
\hline 1. & $\begin{array}{l}\text { Bacillus subtilis } \\
\text { IB-21 }\end{array}$ & Wheat & $\begin{array}{l}\text { Stimulate } \\
\text { rhizodeposition }\end{array}$ & Kudoyarova et al. ${ }^{67}$ & 2014 \\
\hline 2. & Micrococcus luteus & Zea mays & Growth promotion & Raza and Faisal ${ }^{68}$ & 2013 \\
\hline 3. & Bacillus subtilis & $\begin{array}{l}\text { Platycladus } \\
\text { orientalis }\end{array}$ & Stomatal conductance & Liu et al. ${ }^{64}$ & 2013 \\
\hline 4. & Bacillus & Lettuce & $\begin{array}{l}\text { Increased growth of } \\
\text { plant }\end{array}$ & Arkhipova et al. ${ }^{66}$ & 2007 \\
\hline 5. & $\begin{array}{l}\text { Pseudomonas, } \\
\text { Bacillus and } \\
\text { Azospirillum }\end{array}$ & Maize & $\begin{array}{l}\text { Increased spike length, } \\
\text { tiller number and } \\
\text { seeds weight }\end{array}$ & Hussain et al. ${ }^{65}$ & 2011 \\
\hline
\end{tabular}


Mesorhizobium ciceri (CR-30 and CR-39), Rhizobium leguminosarum (LR-30), and Rhizobium phaseoli (MR-2) increased root length, biomass and drought tolerant index in seedlings of wheat in presence of polyethylene glycol (PEG) 6000 induced drought ${ }^{94}$. Priming of maize seeds with EPS- producing strains like Alcaligenes faecalis AF3, Proteus penneri $\mathrm{Pp} 1$ and Pseudomonas aeruginosa $\mathrm{Pa} 2$ increased root and shoot length, biomass of plants, and moisture content in soil ${ }^{94}$. Under dehydrated conditions, sunflower showed increase in root tissue when inoculated with EPS-producing bacterial strain YAAF3495. EPS play a pivotal role to maintain water potential, make sure obligate connection among rhizobacteria and roots in stress condition created by drought ${ }^{96}$. Pseudomonas sp. strain P45 improved soil structure through EPS formation to protect sunflower seedlings from dehydration ${ }^{97,91}$. Ghosh et al., (2019) ${ }^{98}$ observed four drought tolerant bacterial strains namely Pseudomonas aeruginosa PM389, P. aeruginosa ZNP1, Bacillus endophyticus J13 and B. tequilensis $\mathrm{J} 12$ were able to alleviate the deterimental effects of osmotic-stress induced in Arabidopsis thaliana by adding $25 \%$ PEG in agar medium. Rhizobium sp., Xanthomonas sp., Agrobacterium sp., Enterobacter cloacae, Bacillus drentensis, Azotobacter vinelandii and Rhizobium leguminosarum play significant function in improving fertility of soil thus sustain agriculture $^{99}$ (Table 7).

Role of osmolytes on drought tolerance in plants Under water deficit condition, plants secrete different forms of osmolytes such as sugar, betaine, proline, polyhydric alcohol or other amino acids or dehydrin (drought stress protein) ${ }^{100}$. PGPR also release osmolytes in drought stress

Table 5. Role of ACC deaminase producing rhizobacteria on plants growth under drought stress condition

\begin{tabular}{|c|c|c|c|c|c|}
\hline S.No. & PGPR & Plant & Impact on plant & Reference & Year \\
\hline 1. & $\begin{array}{l}\text { Agrobacterium } \\
\text { fabrum, Bacillus } \\
\text { amyloliquifaciens }\end{array}$ & Wheat & $\begin{array}{l}\text { Increased grain yield } \\
\text { and biomass }\end{array}$ & Zafar et al. ${ }^{79}$ & 2019 \\
\hline 2. & $\begin{array}{l}\text { Leclercia decarboxylata } \\
\text { and } A \text {. fabrum }\end{array}$ & Wheat & $\begin{array}{l}\text { Elevated nutrients uptake } \\
\text { and high chlorophyll contents }\end{array}$ & Danish et al. ${ }^{78}$ & 2019 \\
\hline 3. & $\begin{array}{l}\text { O. pseudogrignonens } \\
\text { eRJ12, } \\
\text { Pseudomonas sp. RJ15, } \\
\text { and } B \text {. subtilis RJ46 }\end{array}$ & Pea & Decreased ACC accumulation & Saika et al. ${ }^{73}$ & 2018 \\
\hline 4. & $\begin{array}{l}\text { Pseudomonas fluorescens, } \\
\text { Enterobacter hormaechei, } \\
\text { Pseudomonas migulae }\end{array}$ & $\begin{array}{l}\text { Foxtail } \\
\text { millet }\end{array}$ & $\begin{array}{l}\text { Improved seed germination } \\
\text { and seedling growth }\end{array}$ & Niu et $a .^{75}$ & 2017 \\
\hline 5. & $\begin{array}{l}\text { Psuedomonas flourescens } \\
\text { DPB15 and P.palleroniana } \\
\text { DPB16 }\end{array}$ & Wheat & $\begin{array}{l}\text { Enhanced root and } \\
\text { shoot growth }\end{array}$ & Chandra et al. ${ }^{81}$ & 2018 \\
\hline 6. & $\begin{array}{l}\text { Variovorax } \\
\text { paradoxus }\end{array}$ & Pea & $\begin{array}{l}\text { Reduction in ethylene } \\
\text { production, increased growth, } \\
\text { yield and efficiency of water use }\end{array}$ & Belimov et al. ${ }^{82}$ & 2009 \\
\hline 7. & $\begin{array}{l}\text { Pseudomonas } \\
\text { fluorescens }\end{array}$ & Pea & $\begin{array}{l}\text { Enhanced water uptake and } \\
\text { induced longer roots }\end{array}$ & Zahir et al. ${ }^{83}$ & 2008 \\
\hline 8. & $\begin{array}{l}\text { Variovorax } \\
\text { paradoxus }\end{array}$ & Pea & $\begin{array}{l}\text { Increased yield, nitrogen content } \\
\text { and number of seed }\end{array}$ & Dodd et al. ${ }^{77}$ & 2005 \\
\hline 9. & $\begin{array}{l}\text { Achromobacter } \\
\text { piechaudii }\end{array}$ & $\begin{array}{l}\text { Tomato and } \\
\text { Pepper }\end{array}$ & Increased fresh and dry weight & Mayak et al. ${ }^{74}$ & 2004 \\
\hline 10. & B. licheniformis & Pepper & $\begin{array}{l}\text { Increased expression } \\
\text { of stress genes }\end{array}$ & Lim and $\mathrm{Kim}^{84}$ & 2013 \\
\hline 11. & $\begin{array}{l}\text { Bacillus and } \\
\text { Pseudomonas with } \\
\text { Mesorhizobium ciceris }\end{array}$ & Chickpea & $\begin{array}{l}\text { Increased concentration } \\
\text { of proline, improved root } \\
\text { and shoot, length, seed } \\
\text { germination }\end{array}$ & Sharma et al. ${ }^{85}$ & 2013 \\
\hline
\end{tabular}


condition (Table 8). These osmolytes interact with those produced by plants and enhance growth of plants ${ }^{101}$. These secreted solutes trap water molecules which help in decreasing the hydric potential of cells. This kind of regulation is known as osmoregulation. These accumulated solutes increase membrane integrity and protein stability to counteract cellular damage. Bacillus spp. effects osmoregulation by preventing electrolyte leakage and enhancing proline synthesis, sugars, free amino acids accumulation ${ }^{102}$. The function of the osmolytes is to prevent water molecules loss by reducing the cell water potential during drought period. Also, osmolytes help in protecting cellular damage by maintaining the integrity and stability of membranes and proteins in water scarce condition. PGPR consortia lessened the effect of drought stress in rice crop by accumulation of proline which improved the plant growth ${ }^{103}$. Inoculation of $B$. thuringiensis $(\mathrm{Bt})$ in $L$. dentate showed increased shoot proline content in water shortage condition $s^{55}$. Similarly, phosphate solubilizing bacteria Bacillus polymyxa secreted excess proline in tomato plants to induce drought tolerance ${ }^{104}$. Sandhaya et al. $(2010 \mathrm{~b})^{105}$ showed that priming cultivars of rice with consortia containing Pseudomonas jessenii R62, Pseudomonas synxantha R81 and Arthrobacter nitroguajacolicus strain YB3 and YB5 increased plant growth in drought area. This consortium enhanced proline accumulation in plants by up regulating its biosynthetic pathway hence preserving cell water potential, stabilizing the cell membrane and protein during drought stress ${ }^{105}$. It has been reported that enhanced concentration of osmolytes like proline, betaine, glutamate, glycine and trehalose stimulated by Azospirillum help plants to overcome osmotic stress ${ }^{106}$.
Similarly, A. lipoferum metabolic activities lead to accumulation of free amino acids and soluble sugars thus improving maize growth in drought ${ }^{107}$. Pseudomonas putida GAP-P45 enhance plant biomass, relative water content and leaf water potential by stimulating accumulation of proline in maize plants in drought conditions ${ }^{97}$. Azospirillium spp. z19 made maize seedling to tolerate drought stress to a higher level as compared to uninoculated plants due to higher proline levels ${ }^{108}$. Evidences of increased biosynthesis and accumulation of choline, a precursor of gibberellin (GB), showed increased biosynthesis in maize when inoculated with Klebsiella variicola F2, P. fluorescens YX2 and Raoultella planticola YL2.This resulted in upgraded level GB thereby bettering leaf relative water content (RWC) and dry matter weight (DMW) ${ }^{109,110}$. Inoculating plants with PGPR increases existing concentrations of proline in maize plants by $P$. fluorescens under drought stress ${ }^{111}$. Phaseolus vulgaris plants inoculated with Rhizobium showed improved metabolism of carbon and nitrogen and upregulation of trehalose-6-phosphate synthase gene ${ }^{112,113}$. Pseudomonas putida GAP-P45 showed upgraded expression of polyamine biosynthetic genes (ADC, AIH, CPA, SPDS, SPMS and SAMDC) and polyamine levels in Arabidopsis thaliana during drought stress ${ }^{114,98}$.

Role of rhizobacteria on antioxidant defense system for induction of drought tolerance

During normal growth of plant, ROS is produced at low level. Stress condition results into overproduction of ROS which causes oxidative damage. ROS affects signalling, transport, metabolism and biosynthesis of auxin. It also interacts with phytohormones production process, for example, $\mathrm{H}_{2} \mathrm{O}_{2}$ causes ethylene production. In response to the stress condition, antioxidant

Table 6. Role of rhizobacterial-VOCs on plant growth under drought stress condition

\begin{tabular}{|c|c|c|c|c|c|}
\hline S.No. & PGPR & Plant & Impact on plant & Reference & Year \\
\hline 1. & Bacillus thuringiensis & Wheat & $\begin{array}{l}\text { Increased rate of } \\
\text { photosynthesis and reduction } \\
\text { in emission of volatiles }\end{array}$ & Timmusk et al..$^{90}$ & 2014 \\
\hline 2. & Pseudomonas chlororaphis & $\begin{array}{l}\text { Arabidopsis } \\
\text { thaliana }\end{array}$ & $\begin{array}{l}\text { Prevent loss of } \\
\text { water by stomatal closure }\end{array}$ & Cho et al. ${ }^{89}$ & 2008 \\
\hline 3. & $\begin{array}{l}\text { Bacillus spp. (GB03) } \\
\text { and (IN937a), Enterobacter } \\
\text { cloacae JM22 }\end{array}$ & $\begin{array}{l}\text { Arabidopsis } \\
\text { thaliana }\end{array}$ & $\begin{array}{l}\text { Phenotypic } \\
\text { improvement }\end{array}$ & Zhang et al..$^{88}$ & 2010 \\
\hline
\end{tabular}

Journal of Pure and Applied Microbiology 
Table 7. Effect of rhizobacterial-EPS on plant growth under drought stress condition

\begin{tabular}{|c|c|c|c|c|c|}
\hline $\begin{array}{l}\text { S. } \\
\text { No. }\end{array}$ & PGPR & Plant & Impact on plant & Reference & Year \\
\hline 1. & $\begin{array}{l}\text { Pseudomonas aeruginosa } \\
\text { PM389, P. aeruginosa } \\
\text { ZNP1, Bacillus } \\
\text { endophyticus J13 and } \\
\text { B. tequilensis J12 }\end{array}$ & $\begin{array}{l}\text { Arabidopsis } \\
\text { thaliana }\end{array}$ & $\begin{array}{l}\text { Increased in IAA, cytokinin, } \\
\text { gibberellins, and EPS secretion }\end{array}$ & Ghosh et al. ${ }^{99}$ & 2019 \\
\hline 2. & $\begin{array}{l}\text { Proteus perneri, Pseudomonas } \\
\text { aeruginosa, Alcaligenes faecalis }\end{array}$ & Maize & $\begin{array}{l}\text { Enhanced protein, proline, sugar } \\
\text { and relative water content }\end{array}$ & Naseem \& Bano ${ }^{93}$ & 2014 \\
\hline 3. & $\begin{array}{l}R . \text { leguminosarum, } \\
\text { M. ciceri and } R \text {. phaseoli }\end{array}$ & Wheat & $\begin{array}{l}\text { Promoted growth of plant, drought } \\
\text { tolerance index and biomass }\end{array}$ & Hussain et al. ${ }^{56}$ & 2014 \\
\hline 4. & Bacillus thuringienesis & Wheat & $\begin{array}{l}\text { Production of alginate resulted into } \\
\text { drought tolerance }\end{array}$ & Timmusk et al. ${ }^{90}$ & 2014 \\
\hline 5. & Pseudomonas sp. & Sunflower & $\begin{array}{l}\text { Enhanced plant biomass, } \\
\text { RAS/RT ratio }\end{array}$ & Sandhya et al. ${ }^{91}$ & 2009 \\
\hline 6. & P. putida & Maize & Improved physiological response & Vardharajul et al. ${ }^{96}$ & ${ }^{6} 2009$ \\
\hline 7. & Rhizobium sp. YAS34 & Sunflower & $\begin{array}{l}\text { Enhanced ratio of RAS/RT (Root } \\
\text { adhering soil per root tissue) }\end{array}$ & Alami et al. ${ }^{95}$ & 2000 \\
\hline
\end{tabular}

defense system is used by plants, in which plants produce various enzymatic and nonenzymatic antioxidants ${ }^{115}$. It has been observed that enzymatic activities lead to reduction of oxidative damage but at very high level of ROS, it can results into deleterious effects ${ }^{116}$. Thus, it is important to maintain balance between ROS production and annihilation of free radicals produced $^{117}$. This can be done by using PGPR and their inoculation to plants shows higher survival rate by preventing oxidative damage than those which were not inoculated with PGPR.

Pseudomonas $\mathrm{sp}$. is reported to improve catalase activity in drought stress condition in basil plants (Ocimum basilicum L.). Similarly, Pseudomonas sp., Bacillus lentus and A. brasilense consortium induce high activity of glutathione peroxidase and ascorbate peroxidase in Ocimum basilicum L. ${ }^{118}$. Consortium of PGPR containing $P$. jessenii R62, $P$. synxantha R81 and A. nitroguajacolicus strainYB3 and YB5 improved growth of plant along with inducing superoxide dismutase, catalase (CAT), peroxidase (PX), ascorbate peroxidase (APX) and lowering $\mathrm{H}_{2} \mathrm{O}_{2}$, malondialdehyde (MDA) in Sahbhagi (drought tolerance) and IR-64 (drought sensitive) rice crop $^{103}$. Pseudomonas spp. namely $P$. entomophila, P. stutzeri, P. putida, P. syringae and P. montelli are responsible for reducing action of antioxidant enzymes significantly in maize under drought stress $^{97}$. Bacillus species have also shown protection against drought stress by decreasing antioxidant enzymes APX and glutathione peroxidase (GPX) ${ }^{96}$. $B$. thuringiensis $(\mathrm{Bt})$ improved growth via drought avoidance and reduction of glutathione reductase (GR) and ascorbate peroxidase (APX) activity in Lavandula dentata and Salvia officinalis in drought conditions ${ }^{55}$. Streptomyces pactum Act12 treatment in wheat increased osmoregulation and antioxidant efficiency of plants. Bacillus pumilus DH-11 and B. firmus 40 induced ROSscavenging enzymes like ascorbate peroxidase and catalase in tomato plants. A remarkable increase in antioxidant enzymes like APX, SOD, and CAT was evident under drought stress in PGPR treated plants compared with non-treated plants ${ }^{119,120}$. Increased activity of CAT in green gram plants inoculated with Pseudomonas fluorescens Pf1 and Bacillus subtilis EPB was reported by Saravanakumar et al. (2011) ${ }^{121}$. Similarly, increased level of CAT production and drought tolerance has also been correlated in cucumber ${ }^{122}$ and maize $^{96,98,123}$. Up-regulation of expression of drought resistance-related genes like EXPA2, EXPA6, P5CS, SAMSI HSP17.8 and SnRK2 and accumulation of abscisic acid mitigated drought stress impact in wheat ${ }^{124,119}$. These experimental evidences proves that PGPR have significant role in increasing plant tolerance towards drought (Table 9). 


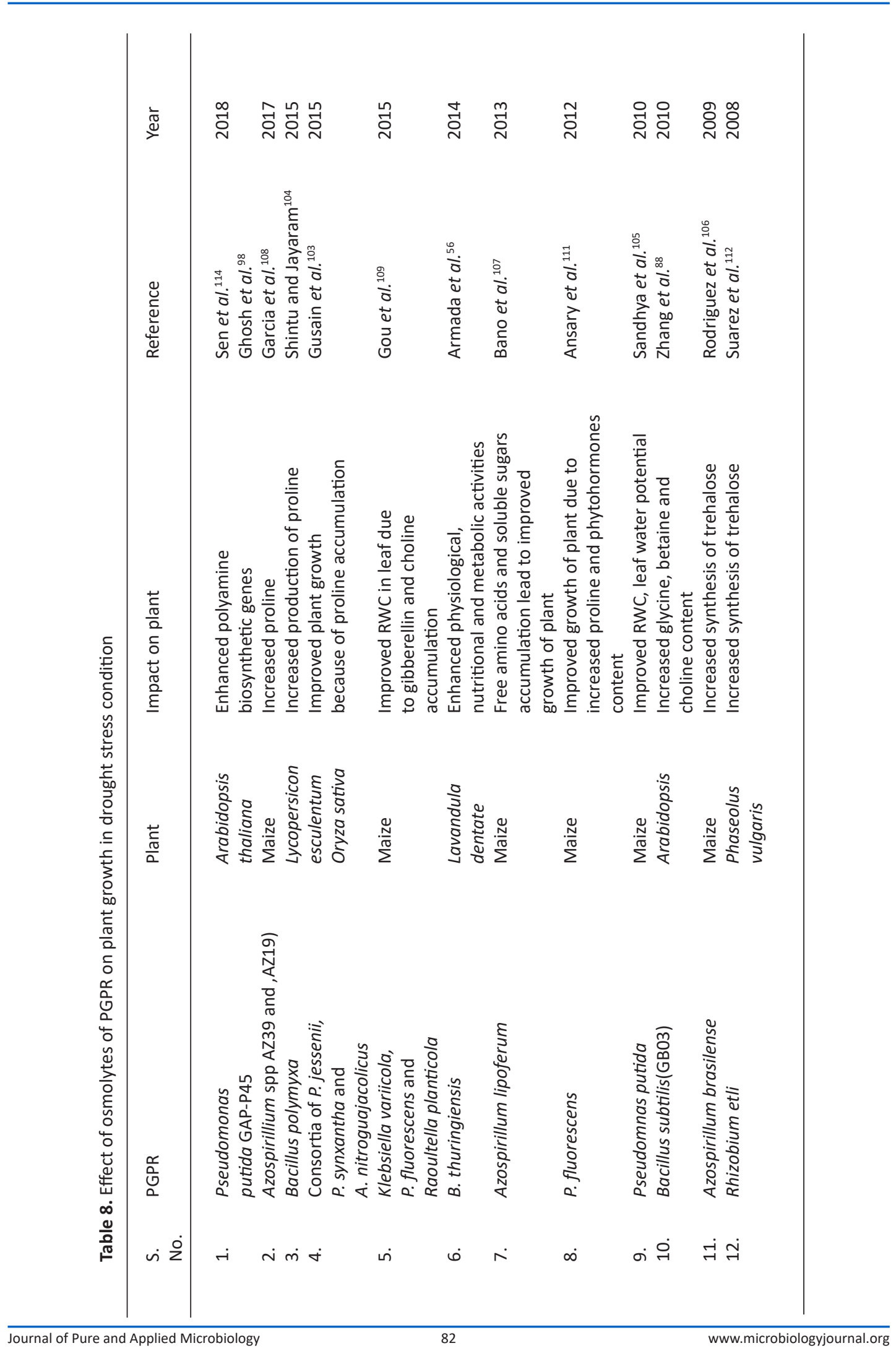




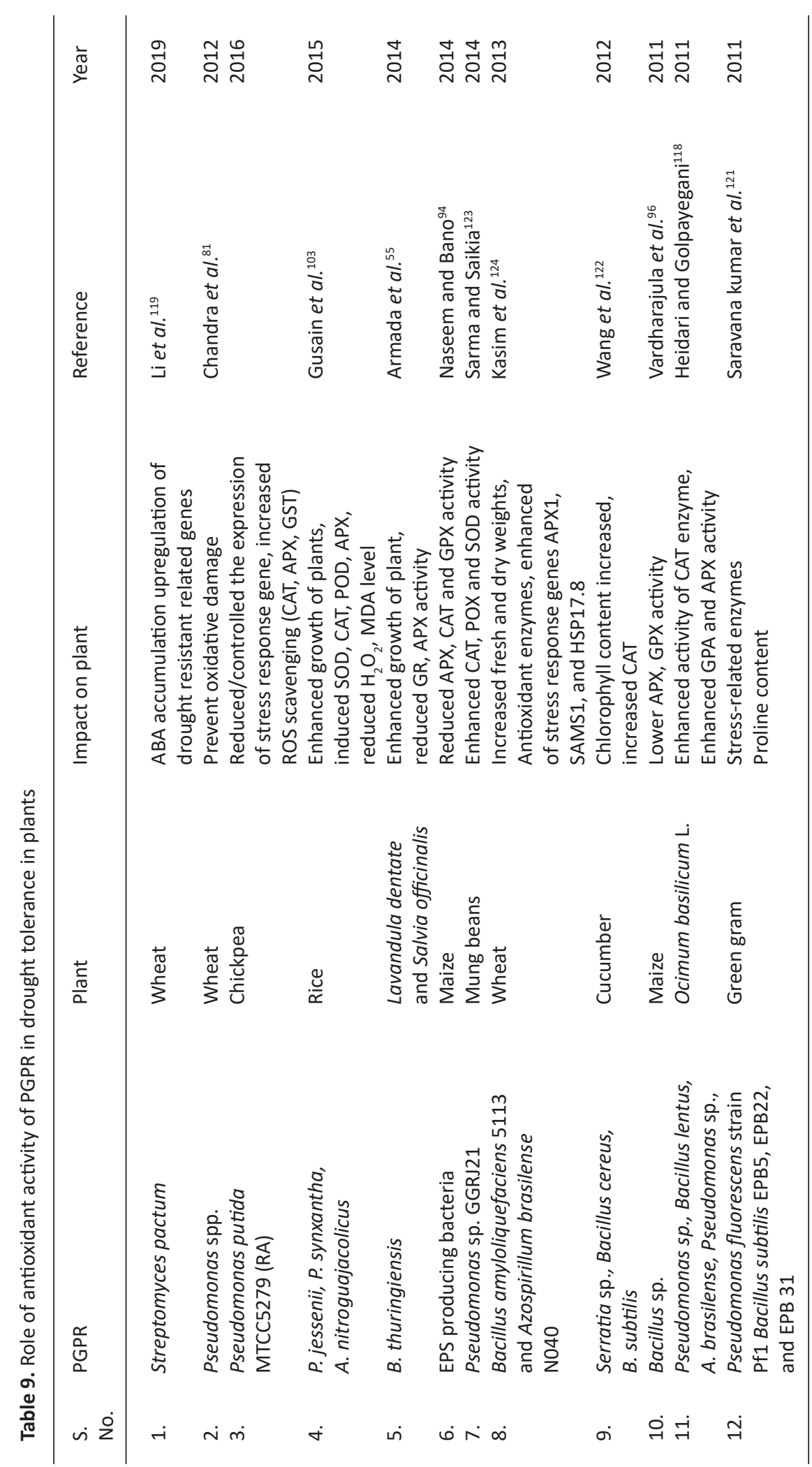




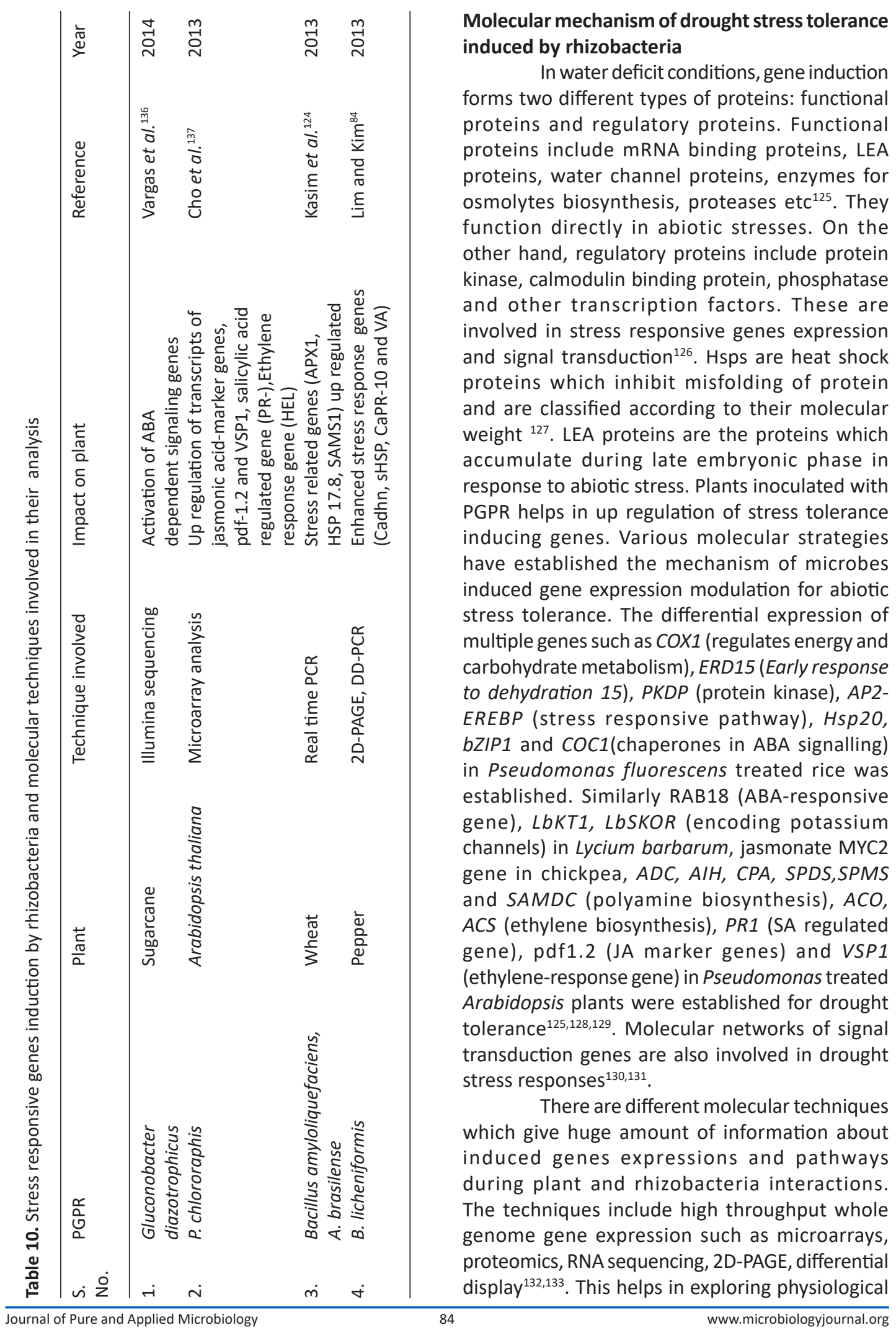


functions of such genes and tolerance induced by PGPR ${ }^{134}$. Upregulation of EARLY RESPONSE TO DEHYDRATION 15 (ERD15) in Arabidopsis thaliana was seen when inoculated with Paenibacillus polymyxa B2 as investigated at transcriptional level ${ }^{135}$. Pepper plants when inoculated with Bacillus showed more than 1.5-folds increase in Cadhn, VA, sHSP and CaPR-1084. Inoculation of Bacillus amyloliquefaciens 5113 and $A$. brasilense NO40 alleviating the deleterious impact of drought stress in leaves of wheat by upregulation of stress response genes APX1, SAMS1, and HSP17.8. These upregulated genes enhanced plant ascorbate-glutathione redox cycle help in alleviating drought stress ${ }^{124}$. Bacterial priming of
Gluconacetobacter diazotrophicus PAL5 stimulated the ABA-dependent signalling genes which confer tolerance to drought in sugarcane cV. SP701143 as studied by Illumina sequencing (HiSeq 2000 system) ${ }^{135,136}$ (Table 10). In Pseudomonas chlororaphis colonized Arabidopsis thaliana plants, upregulated but differential expression of jasmonic acid-marker genes, VSP1 and $p d f-1.2$, salicylic acid regulated gene, PR-1 and the ethylene-response gene, was observed ${ }^{137}$.

In the past several decades, researchers have been able develop many resistant varieties of plant species, but they have gained a very little success in development of drought tolerant crops using genetic engineering ${ }^{138}$. Monsanto introduced

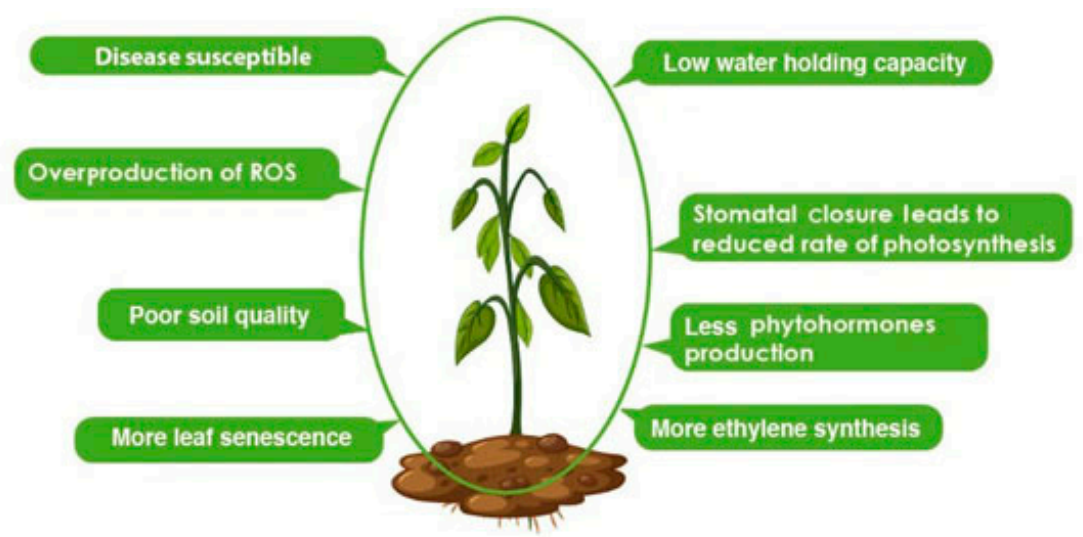

a) Poor plant growth without PGPR under drought stress

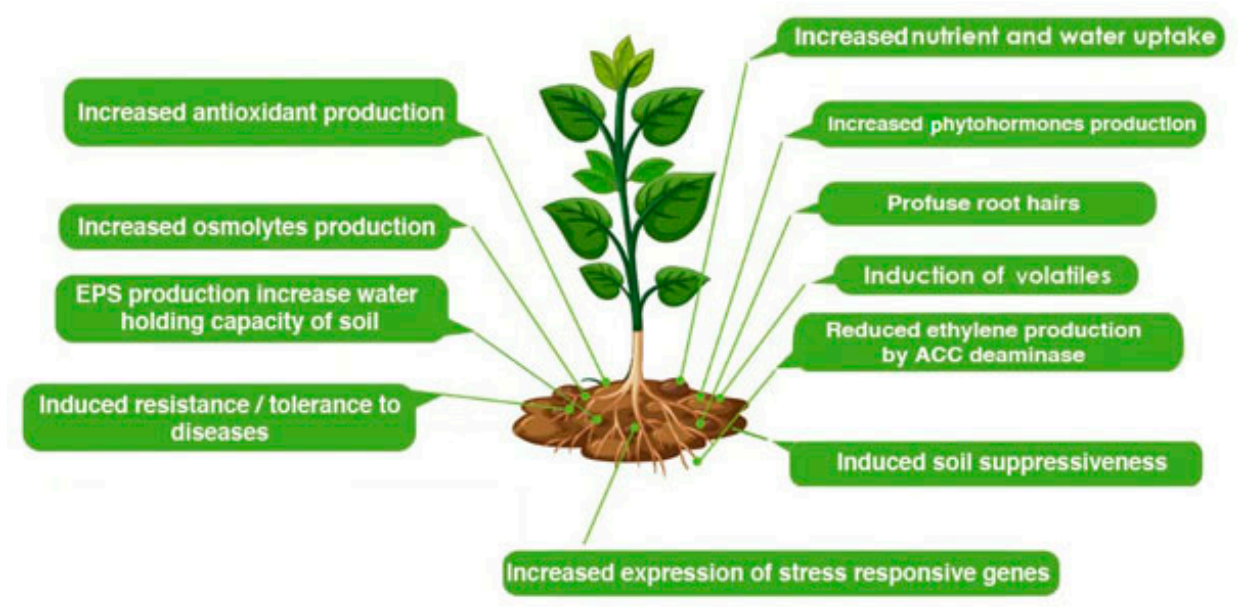

b) Enhanced plant growth with PGPR under drought stress

Fig. 1. Strategies used by PGPR to modulate plant growth under stress conditions (a) Poor plant growth without PGPR and (b) Enhanced plant growth with PGPR 
GM crop MON 87460, a maize (Zea mays L), in 2009 which was drought stress tolerant. This crop increased production 5.5-folds from 50,000 ha in 2013 to 275,000 ha in 2014 . Cold shock protein B (CSPB) inserted from Bacillus subtilis in MON 87460 expresses to imparted drought tolerance ${ }^{139,140}$. In bacteria, cold shock proteins help in preserving normal cellular functions by stabilizing cellular RNA and enhancing gene expression under abiotic stress $^{141}$. Similarly, the translation of CSPB have been reported to enhance tolerance to abiotic stress in Arabidopsis and rice ${ }^{142}$. Another important gene OsNLI-IF overexpressed by cold, heat, salt and drought stresses improved drought tolerance in transgenic tobacco plants ${ }^{143}$. Argentina developed genetically modified soybean contains a gene from a naturally drought-resistant sunflower adapted to drought. Rhizospheric microbes not only support the growth of plants in limited water conditions but also reduce use of chemical fertilisers.

The rhizosphere research field is flooded with metagenomics and metabolomics data, establishing genes identity and their functional taxonomic relationships. Scientists are putting their research efforts on developing consortia of microbes and metabolites of microbial origin in the formulations that best suited for individual crops in stressed environment ${ }^{144}$.

\section{CONCLUSION}

In this review, we have attempted to highlights the existing knowledge of plant-bacterial interactions in maintaining plant growth under drought stress. To overcome drought conditions, plants adapt various morphological, biochemical and physiological changes. Now, it has been established that members of the rhizospheric bacteria can alleviate abiotic stress of drought in plants. This can be a promising alternative to tedious and costly genetic engineering and plant breeding methods. This review establishes that various PGPR play significant role in inducing tolerance to drought stress in plants employing different mechanisms. The rhizobacterial induced drought stress tolerance in the plant is over and above the drought resistance genes either present or absent in the plant (Fig. 1).

\section{Future Perspectives}

Future research should be undertaken to increase crop yield, soil fertility and shelf life of products of PGPRs. Drought stress is a severe environmental factor that limits agricultural productivity. Rhizobacteriome offer plethora of PGPR in imparting adaptation and tolerance to drought stresses and prove to be promising strategy to improve productivity in drought areas. The plant and rhizobacteria interaction changes plant as well as soil properties in drought conditions. Rhizobacterial stimulation of osmotic responses and induction of novel genes expression play a significant role in ensuring plant survival under drought stress conditions. The development of drought tolerant crop varieties through genetic engineering and plant breeding approaches is good option but it is a labor intensive, lengthy and costly affair. Alternately, rhizobacteria inoculation to mitigate drought stresses in plants is environment friendly and safe option for agriculture drought affected areas. Future research must focus on (1) identification and characterization of the novel abiotic stress-tolerant bacteria from unexplored niches, (2) discover novel bacteria with novel molecule or mechanism, (3) better formulation with appropriate delivery system and (4) perform rigorous field trial in order to select potential rhizobacterial candidate to combat drought stress.

\section{ACKNOWLEDGEMENTS}

Authors would like to express thanks to Amity University, Noida, Uttar Pradesh and ICAR-NBAIM, Maunath Bhanjan, Uttar Pradesh for support extended in writing this review.

\section{CONFLICT OF INTEREST}

The authors declare that there is no conflict of interest.

\section{FUNDING}

None.

\section{AUTHORS' CONTRIBUTION}

All authors have made substantial contribution to develop this manuscript. 


\section{DATA AVAILABILITY}

All datasets generated or analyzed during this study are included in the manuscript.

\section{ETHICS STATEMENT}

This article does not contain any studies with human participants or animals performed by any of the authors.

\section{REFERENCES}

1. Lesk, C., Rowhani, P., and Ramankutty, N. Influence of extreme weather disasters on global crop production. Nature 2016; 529:84-87. doi: 10.1038/nature16467

2. Wang $W$, Vinocur B, \& Altman A. Plant responses to drought,salinity and extreme temperatures: towards genetic engineering for stress tolerance. Planta. 2003; 218:1-14. https://doi.org/10.1007/s00425-003-1105-5

3. Sandhya V, Ali SZ, Grover M, Kishore N, Venkateswarlu B. Pseudomonas sp. strain P45 protects sun flowers seedlings from drought stress through improved soil structure. J. Oilseed Res., 2009a; 26: 600-601.

4. Govindasamy V, George P, Kumar M. et al. Multi-trait PGP rhizobacterial endophytes alleviate drought stress in a senescent genotype of sorghum [Sorghum bicolor (L.) Moench]. 3 Biotech, 2020; 10(13). https://doi. org/10.1007/s13205-019-2001-4

5. Grover M, Ali SKZ, Sandhya V, Rasul A and Venkateswarlu B. Role of microorganisms in adaptation of agriculture crops to abiotic stresses. World J. Microbiol. Biotechnol., 2011; 27: 1231-1240. https:// doi.org/10.1007/s11274-010-0572-7

6. Ahmad F, Ahmad I, Khan MS. Screening of freeliving rhizospheric bacteria for their multiple plant growth promoting activities. Microbiol. Res., 2008; 163(2): 173-181. https://doi.org/10.1016/j. micres.2006.04.001

7. Hayat R, Ali S, Amara U, Khalid R, Ahmed I. Soil beneficial bacteria and their role in plant growth promotion: a review. Ann. Microbiol., 2010; 60: 579598. https://doi.org/10.1007/s13213-010-0117-1

8. Pii Y, Mimmo T, Tomasi N, Terzano R, Cesco S, Crecchio C. Microbial interactions in the rhizosphere: beneficial influences of plant growth-promoting rhizobacteria on nutrient acquisition process: a review. Biol. Fertil. Soils, 2015; 51(4): 403-415. https://doi.org/10.1007/ s00374-015-0996-1

9. Braud A, Jezequel K, Bazot S, Lebeau T. Enhanced phytoextraction of an agricultural $\mathrm{Cr}-, \mathrm{Hg}$ - and $\mathrm{Pb}$-contaminated soil by bioaugmentation with siderophore producing bacteria. Chemosphere, 2009; 74: 280-286. https://doi.org/10.1016/j. chemosphere.2008.09.013

10. Ahemad M. Implications of bacterial resistance against heavy metals in bioremediation: a review. IIOABJ., 2012; 3: 39-46.

11. Deikman J, Petracek M, Heard JE. Drought tolerance through biotechnology: improving translation from the laboratory to farmers' fields. Curr. Opin Biotechnol., 2012; 23: 243-250. https://doi.org/10.1016/j. copbio.2011.11.003
12. Ahemad M, Kibret M. Mechanisms and applications of plant growth promoting rhizobacteria: Current perspective. King Saud Univ. Sci., 2014; 26(1): 1-20. https://doi.org/10.1016/j.jksus.2013.05.001

13. Tank N, Saraf M. Salinity-resistant plant growth promoting rhizobacteria ameliorates sodium chloride stress on tomato plants. J. Plant Interact.,2010; 5: 51-58. https://doi.org/10.1080/17429140903125848

14. Glick BR. Plant growth-promoting bacteria: Mechanisms and applications. Scientifica., 2012;15. https://doi.org/10.6064/2012/963401

15. Ullah A, Manghwar H, Shaban, M et al. Phytohormones enhanced drought tolerance in plants: A coping strategy. Environ Sci. Pollut. Res., 2018;25,3310333118. https://doi.org/10.1007/s11356-018-3364-5

16. Ghosh D, Gupta A, Mohapatra S. Dynamics of endogenous hormone regulation in plants by phytohormone secreting rhizobacteria under waterstress. Symbiosis, 2019; 77: 265-278. https://doi. org/10.1007/s13199-018-00589-w

17. Khan MS, Zaidi A, Ahemad M, Oves M, Wani PA. Plant growth promotion by phosphate solubilising fungi Current perspective. Arch Agron Soil Sci., 2010; 56: 73-98. https://doi.org/10.1080/03650340902806469

18. Arshad M, Saleem, M, Hussain S. Perspectives of bacterial ACC deaminase in phytoremediation. Trends Biotechnol., 2007; 25: 356- 362. https://doi. org/10.1016/j.tibtech.2007.05.005

19. Anjum MA, Sajjad MR, Akhtar N, Qureshi MA, Iqbal A, Rehman JA, Mahmud-ul-Hasan, Response of cotton to plant growth promoting rhizobacteria (PGPR) inoculation under different levels of nitrogen. J. Agric. Res., 2007; 45: 135-143.

20. Ali SKZ, Sandhya V, Rao LV, 2014. Isolation and characterization of drought-tolerant ACC deaminase and exopolysaccharide-producing fluorescent Pseudomonas sp. Ann. Microbiol., 2014; 64: 493-502. https://doi.org/10.1007/s13213-013-0680-3

21. Burd GI, Dixon DG, Glick BR. Plant growth promoting bacteria that decrease heavy metal toxicity in plants. Can. J. Microbiol., 2000; 46: 237-245. https://doi. org/10.1139/w99-143

22. Bashan $Y$, de-Bashan LE, Prabhu SR, Hernandez JP. Advances in plantgrowth-promoting bacterial inoculant technology: formulations and practical perspectives (1998-2013). Plant Soil, 2014; 378: 1-33. https://doi.org/10.1007/s11104-013-1956-x

23. Nehra V, Choudhary M. A review on plant growth promoting rhizobacteria acting as bioinoculants and their biological approach towards the production of sustainable agriculture. J. Appl. Nat. Sci., 2015; 7(1): 540-556. https://doi.org/10.31018/jans.v7i1.642

24. Naylor D and Coleman-Derr D. Drought stress and root-associated bacterial communities. Front. Plant Sci., 2018; 8: 2223. https://doi.org/10.3389/ fpls.2017.02223

25. Van Meeteren MJM, Tietema A, van Loon EE, Verstraten JM. Microbial dynamics and litter decomposition under a changed climate in a Dutch heathland. Appl. Soil Ecol., 2008; 38: 119-127. https://doi.org/10.1016/j. apsoil.2007.09.006

26. Yang J, Kloepper JW, Ryu CM, Rhizosphere bacteria help 
plants tolerate abiotic stress. Trends Plant Sci, 2009; 14: 1-4. https://doi.org/10.1016/j.tplants.2008.10.004

27. Nardi S, Concheri G, Pizzeghello D, Sturaro A, Rella R, Parvoli G. Soil organic matter mobilization by root exudates. Chemosphere., 2000; 5: 653-658. https:// doi.org/10.1016/50045-6535(99)00488-9

28. Hiltner L. UeberneuereErfahrungen und Probleme auf dem Gebiete der Bodenbakteriologie und unterbesondererBerUcksichtigung der Grundungung und Brache. Arb. Deut. Landw. Gesell., 1904; 98: 59-78.

29. Zhang $Q$, Saleem $M$ and Wang $C$. Probiotic strain Stenotrophomonas acidaminiphila BJ1 degrades and reduces chlorothalonil toxicity to soil enzymes, microbial communities and plant roots. AMB Express, 2017; 7: 227-235. https://doi.org/10.1186/s13568017-0530-y

30. Dakora FD, Phillips DA. Root exudates as mediators of mineral acquisition in low-nutrient environments. Plant Soil, 2002; 245: 35-47. https://doi. org/10.1023/A:1020809400075

31. Hartmann A, Rothballer M and M Schmid. Lorenz Hiltner, a pioneer in rhizosphere microbial ecology and soil bacteriology research. Plant Soil, 2008; 312: 7-14. https://doi.org/10.1007/s11104-007-9514-z

32. Bonkowski M, Villenave $\mathrm{C}$ and Griffiths B. Rhizosphere fauna: the functional and structural diversity of intimate interactions of soil fauna with plant roots. Plant Soil, 2009; 321: 213-233. https://doi.org/10.1007/s11104009-0013-2

33. Buee $M$, De Boer $W$, Martin F, van Overbeek $L$ and Jurkevitch $E$. The rhizosphere zoo: an overview of plant-associated communities of microorganisms, including phages, bacteria, archaea, and fungi, and of some of their structuring factors. Plant Soil, 2009; 321: 189-212. https://doi.org/10.1007/s11104-009-9991-3

34. Bakker PA, Berendsen RL, Doornbos RF, Wintermans PC, Pieterse CM. The rhizosphere revisited: root microbiomics. Front Plant Sci., 2013; 4: 165-172. https://doi.org/10.3389/fpls.2013.00165

35. Doornbos RF, Van Loon LC, Bakker PAHM. Impact of root exudates and plant defense signaling on bacterial communities in the rhizosphere. Agron. Sustain. Dev., 2012; 32: 227-243. https://doi.org/10.1007/s13593011-0028-y

36. Raaijmakers J \& Mazzola M. Diversity and natural functions of antibiotics produced by beneficial and pathogenic soil bacteria. Annu. Rev. Phytopathol., 2012; 50: 403-424. https://doi.org/10.1146/annurevphyto-081211-172908

37. Hueso, S, Garcia C and Hernandez T. Severe drought conditions modify the microbial community structure, size and activity in amended and unamended soils. Soil Biol. Biochem., 2012; 50: 167-173. https://doi. org/10.1016/j.soilbio.2012.03.026

38. Bouskill NJ, Wood TE, Baran R, Ye Z, Bowen BP, Lim H, et al. Belowground response to drought in a tropical forest soil. I. Changes in microbial functional potential and metabolism. Front. Microbiol., 2016; 7: 525-536. https://doi.org/10.3389/fmicb.2016.00525

39. Fuchslueger L, Bahn M, Hasibeder R, Kienzl S, Fritz $\mathrm{K}$, Schmitt $\mathrm{M}$, et al. Drought history affects grassland plant and microbial carbon turnover during and after a subsequent drought event. J. Ecol., 2016; 104: 14531465. https://doi.org/10.1111/1365-2745.12593

40. Toth Z, Tancsics A, Kriszt B, Kroel-Dulay G, Onodi G and Hornung E. Extreme effects of drought on composition of the soil bacterial community and decomposition of plant tissue: bacterial community and plant tissue decomposition. Eur. J. Soil Sci., 2017; 68: 504-513. https://doi.org/10.1111/ejss.12429

41. Barnard RL, Osborne CA and Firestone MK. Responses of soil bacterial and fungal communities to extreme desiccation and rewetting. ISME J., 2013; 7: 22292241. https://doi.org/10.1038/ismej.2013.104

42. Acosta-Martinez V, Cotton J, Gardner T, Moore-Kucera J, Zak J, Wester D, et al. Predominant bacterial and fungal assemblages in agricultural soils during a record drought/heat wave and linkages to enzyme activities of biogeochemical cycling. Appl. Soil Ecol., 2014; 84: 69-82. https://doi.org/10.1016/j.apsoil.2014.06.005

43. Abd EI-Daim IA, Bejai S \& Meijer J. Bacillus velezensis 5113 Induced metabolic and molecular reprogramming during abiotic stress tolerance in wheat. Sci Rep., 2019; 9: 16282. https://doi.org/10.1038/s41598-01952567-x

44. Rolli E, Marasco R, Vigani G, Ettoumi B, Mapelli $\mathrm{F}$, Deangelis $\mathrm{ML}$, et al. Improved plant resistance to drought is promoted by the root-associated microbiome as a water. Environ Microbiol., 2015; 17(2): 316-31. https://doi.org/10.1111/1462-2920.12439

45. Fahad S, Hussain S, Bano A, Saud S, Hassan S, Shan $D$, et al. Potential role of phytohormones and plant growth-promoting rhizobacteria in abiotic stresses: consequences for changing environment. Environ. Sci. Pollut. Res., 2015; 22: 4907-4921. https://doi. org/10.1007/s11356-014-3754-2

46. Urano K, Maruyama K, Jikumaru Y, Kamiya Y, Yamaguchi -Shinozaki K and Shinozaki K. Analysis of plant hormone profiles in response to moderate dehydration stress. Plant J., 2017 ; 90: 17-36. https://doi.org/10.1111/ tpj.13460

47. Tiwari S, Lata C, Chauhan PS, Nautiyal CS. Pseudomonas putida attunes morphophysiological, biochemical and molecular responses in Cicer arietinum L. during drought stress and recovery. Plant Physiol Biochem., 2016; 99: 108-117. https://doi.org/10.1016/j. plaphy.2015.11.001

48. Wani PA, Khan MS. Bacillus species enhance growth parameters of chickpea (Cicer arietinum L.) in chromium stressed soils. Food Chem. Toxicol., 2010; 48: 3262-3267. https://doi.org/10.1016/j. fct.2010.08.035

49. Dimkpa C, Weinand T, Asch F. Plant-rhizobacteria interactions alleviate abiotic stress conditions. Plant Cell Environ., 2009a; 32: 1682-1694. https://doi. org/10.1111/j.1365-3040.2009.02028.x

50. Cohen AC, Travaglia CN, Bottini R, Piccoli PN. Participation of abscisic acid and gibberellins produced by endophytic Azospirillum in the alleviation of drought effects in maize. Botanique., 2009; 87: 455-462. https://doi.org/10.1139/B09-023

51. Arzanesh MH, Alikhani HA, Khavazi K, Rahimian HA, Miransari M. Wheat (Triticum aestivum L.) growth enhancement by Azospirillum sp. under drought stress. 
World J. Microbiol. Biotechnol., 2011; 27: 197-205. https://doi.org/10.1007/s11274-010-0444-1

52. Molina-Favero C, Creus CM, Simontacchi M, Puntarulo S, Lamattina L Aerobic nitric oxide production by Azospirillum brasilense Sp245 and its influence on root architecture in tomato. Mol. Plant Microb. Interact., 2008; 2: 1001-1009. https://doi.org/10.1094/MPMI21-7-1001

53. Dimkpa CO, Svatos A, Dabrowska P, Schmidt A, Boland $W$, Kothe $E$.Involvement of siderophores in the reduction of metal-induced inhibition of auxin synthesis in Streptomyces spp. Chemosphere. 2008 ; 74(1): 1925. doi: 10.1016/j.chemosphere.2008.09.079

54. Creus CM, Sueldo RJ, Barassi CA. Water relations and yield in Azospirillum-inoculated wheat exposed to drought in the field. Can. J. Bot., 2004; 82: 273-281. https://doi.org/10.1139/b03-119

55. Armada E, Roldan A, Azcon R, Differential activity of autochthonous bacteria in controlling drought stress in native Lavandula and Salvia plants species under drought conditions in natural arid soil. Microb. Ecol., 2014; 67: 410-420. https://doi.org/10.1007/s00248013-0326-9

56. Hussain MB, Zahir ZA, Asghar HN, Asgha M. Can catalase and exopolysaccharides producing rhizobia ameliorate drought stress in wheat?. Int. J. Agric. Biol., 2014; 16: 3-13.

57. Marulanda A, Barea J-M, Azcon R Stimulation of plant growth and drought tolerance by native microorganisms (AM fungi and bacteria) from dry environments: mechanisms related to bacterial effectiveness. J. Plant Growth Regul., 2009; 28: 115-124. https://doi.org/10.1007/s00344-009-9079-6

58. Omara AED and Elbagory M. Enhancement of plant growth and yield of wheat (Triticum aestivum L.) under drought conditions using plant-growth-promoting bacteria. Ann Res Rev Biol, 2018; 28(6): 1-18. https:// doi.org/10.9734/ARRB/2018/44181

59. Joo GJ, Kin YM, Kim JT, Rhee IK, Kim JH, Lee IJ. Gibberellins-producing rhizobacteria increase endogenous gibberellins content and promote growth of red peppers. Microbiol., 2005; 43: 510-515.

60. Sang S-M, Radhakrishnan R, Khan al et al. Gibberellin secreting rhizobacterium, Pseudomonas putida $\mathrm{H}-2$ 3 modulates the hormonal and stress physiology of soybean to improve the plant growth under saline and drought conditions. Plant Physiol. Biochem., 2014b; 84: 115-124. https://doi.org/10.1016/j. plaphy.2014.09.001

61. Kaushal M, Wani SP. Plant-growth-promoting rhizobacteria: drought stress alleviators to ameliorate crop production in drylands. Ann. Microbiol., 2015; 1-8. https://doi.org/10.1007/s13213-015-1112-3

62. Vishwakarma K, Upadhyay N, Kumar N, Yadav G, Singh J, Mishra RK, Kumar V, Verma R, Upadhyay RG, Pandey $M$, et al. Abscisic acid signaling and abiotic stress tolerance in plants: a review on current knowledge and future prospects. Front Plant Sci., 2017; 8: 161. https://doi.org/10.3389/fpls.2017.00161

63. Bresson J, Varoquaux F, Bontpart T, Touraine B, Vile D. The PGPR strain Phyllobacterium brassicacearum STM196 induces a reproductive delay and physiological changes that result in improved drought tolerance in Arabidopsis. New Phytol., 2013; 558-569. https://doi. org/10.1111/nph.12383

64. Liu F, Xing S, Ma H, Du Z, Ma B. Cytokinin producing, Plant growth promoting rhizobacteria that confer resistance to drought stress in Platycladus orientalis container seedlings. Appl.Microbio.Biotechnol., 2013; 97:9155-9164. https://doi.org/10.1007/s00253-0135193-265.

65. Hussain, A and Hasnain S. Cytokinin production by some bacteria: its impact on cell division in cucumber cotyledons. Afr. J. Microbiol. Res., 2009; 3: 704-712.

66. Arkhipova TN, Prinsen E, Veselov SU, Martinenko EV, Melentiev Al, Kudoyarova GR Cytokinin producing bacteria enhances plant growth in drying soil. Plant Soil, 2007; 292: 305-315. https://doi.org/10.1007/ s11104-007-9233-5

67. Kudoyarova GR, Melentiev AI, Martynenko EV, Timergalina LN, Arkhipova TN, Shendel GV, et al. Cytokinin producing bacteria stimulate amino acid deposition by wheat roots. Plant Physiol. Biochem., 2014; 83: 285-291. https://doi.org/10.1016/j. plaphy.2014.08.015

68. Raza FA, Faisal M. Growth promotion of maize by dessication tolerant Micrococcus luteus chp37 isolated from Cholistan desert, Pakistan. Aust. J.Crop Sci., 2013; 7(11): 1693-1698.

69. Soni R, Yadav SK, Rajput AS. ACC-deaminase producing rhizobacteria: prospects and application as stress busters for stressed agriculture. In: Panpatte D., Jhala Y., Shelat H., Vyas R. (eds) Microorganisms for Green Revolution., 2018; Springer, Singapore. https://doi. org/10.1007/978-981-10-7146-1_9

70. Glick BR. Bacteria with ACC deaminase can promote plant growth and help to feed the world. Microbiol Res., 2014; 169(1): 30-39. https://doi.org/10.1016/j. micres.2013.09.009

71. Gupta S and Pandey S. Unravelling the biochemistry and genetics of ACC deaminase-An enzyme alleviating the biotic and abiotic stress in plants. Plant Gene, 2019; 18: 100175. https://doi.org/10.1016/j. plgene.2019.100175

72. Saleem AR, Brunetti C, Khalid A, Della Rocca G, Raio A, Emiliani G, et al. Drought response of Mucuna pruriens (L.) DC. inoculated with ACC deaminase and IAA producing rhizobacteria. PLOS ONE, 2018; 13(2): e0191218. https://doi.org/10.1371/journal. pone.0191218

73. Saikia J, Sarma R K, Dhandia R, Yadav A, Bharali R, Gupta V K, et al. Alleviation of drought stress in pulse crops with ACC deaminase producing rhizobacteria isolated from acidic soil of Northeast India. Sci. Rep., 2018; 8: 3560 (1-16). https://doi.org/10.1038/s41598018-25174-5

74. Mayak S, Tirosh T, Glick BR. Plant growth-promoting bacteria confer resistance in tomato plants to salt stress. Plant Physiol. Biochem., 2004; 42: 565-572. https://doi.org/10.1016/j.plaphy.2004.05.009

75. Niu X, Song L, Xiao Y, \& Ge, W. Drought-tolerant plant growth-promoting rhizobacteria associated with foxtail millet in a semi-arid agroecosystem and their potential in alleviating drought stress. Front. Micrbiol., 2017; 8: 
2580. https://doi.org/10.3389/fmicb.2017.02580

76. Safari D, Jamali F, Nooryazdan HR, and Bayat F. Evaluation of ACC deaminase producing 'Pseudomonas fluorescens' strains for their effects on seed germination and early growth of wheat under salt stress. Aust. J. Crop Sci., 2018; 12: 413-421. https:// doi.org/10.21475/ajcs.18.12.03.pne801

77. Dodd AA, Belimov WY, Sobeih VI, Safronova D, Grierson D, Davies WJ. Will modifying plant ethylene status improve plant productivity in water-limited environments? 2005.4 ${ }^{\text {th }}$ International Crop Science Congress.

78. Danish S, Zafar-ul-Hye M, Hussain M, Shaaban M, Nunez-Delgado A, Hussain S, Qayyum MF. Rhizobacteria with ACC-deaminase activity improve nutrient uptake, chlorophyll contents and early seedling growth of wheat under PEG-induced osmotic stress. Intl. J. Agric. Biol., 2019; 21: 1212-1220.

79. Zafar-ul-Hye M, Danish S, Abbas M, Ahmad M, Munir TM. ACC deaminase producing PGPR Bacillus amyloliquefaciens and Agrobacterium fabrum along with biochar improve wheat productivity under drought stress. Agronomy, 2019; 9: 343. https://doi. org/10.3390/agronomy9070343

80. Maxton A, Singh P, Masih SA. ACC deaminaseproducing bacteria mediated drought and salt tolerance in Capsicum annuum. J Plant Nutrit., 2018; 41(5): 574-583. https://doi.org/10.1080/01904167.2 017.1392574

81. Chandra D, Srivastava R, Sharma AK. Influence of IAA and ACC deaminase producing fluorescent Pseudomonads in alleviating drought stress in wheat (Triticum aestivum). Agri. Res., 2018; 7. https://doi. org/10.1007/s40003-018-0305-y

82. Belimov AA, Dodd IC, Hontzeas N, Theobald JC, Safronova VI, Davies WJ. Rhizosphere bacteria containing 1-aminocyclopropane-1-carboxylate deaminase increase yield of plants grown in drying soil via both local and systemic hormone signalling. New Phytol., 2009; 181: 413-423. https://doi.org/10.1111/ j.1469-8137.2008.02657.x

83. Zahir ZA, Munir A, Asghar HN, Shahroona, Arshad $M$. Effectiveness of rhizobacteria containing ACCdeaminase for growth promotion of peas (P. sativum) under drought conditions. J. Microbiol. Biotechnol., 2008; 18: 958-963.

84. Lim JH, Kim SD. Induction of drought stress resistance by multi-functional PGPR Bacillus licheniformis K11 in pepper. Plant Pathol. J., 2013; 29: 201-208. https:// doi.org/10.5423/PPJ.SI.02.2013.0021

85. Sharma P, KhannaV, KumarPI. Efficacy of aminocyclopropane-1-carboxylic acid (ACC)deaminase-producing rhizobacteria in ameliorating water stress in chickpea under axenic conditions. Afr. J. Microbiol. Res., 2013; 7: 5749-5757. https://doi. org/10.5897/AJMR2013.5918

86. Raza W, Yousaf S, Rajer FU. Plant growth promoting activity of volatile organic compounds produced by biocontrol strains. Sci. Lett., 2016; 4(1): 40-43.

87. Kanchiswamy CN, Malnoy M, Maffei ME. Chemical diversity of microbial volatiles and their potential for plant growth and productivity. Front. Plant Sci., 2015;
6: 151. https://doi.org/10.3389/fpls.2015.00151

88. Zhang $\mathrm{H}$, Murzello $C$, Sun $\mathrm{Y}, \mathrm{Kim}$ MS, Xie X, Jeter RM, Zak JC, Dowd SE, Pare PW. Choline and osmotic-stress tolerance induced in Arabidopsis by the soil microbe Bacillus subtilis (GB03). Mol Plant Microbe Interact., 2010; 23(8): 1097-104. https://doi.org/10.1094/ MPMI-23-8-1097

89. Cho SM, Kang, B. R., Han, S. H., Anderson, A. J., Park, J.Y., Lee, Y.-H., Cho, B. H., Yang, K.Y., Ryu, C.-M. and Kim, Y.C. 2R,3R-butanediol, a bacterial volatile produced by Pseudomonas chlororaphis O6, is involved in induction of systemic tolerance to drought in Arabidopsis thaliana. Mol. Plant-Microbe Interact. 2008; 21:1067-1075. https://doi.org/10.1094/MPMI21-8-1067

90. Timmusk S, Abd El-Daim, IA, Copolovici L, Tanilas T, Kannaste A, Behers L, Niinemets U. Drought-tolerance of wheat improved by rhizosphere bacteria from harsh environments: enhanced biomass production and reduced emissions of stress volatiles. PLoS One, 2014; 9: e96086. https://doi.org/10.1371/journal. pone.0096086

91. Sandhya V, Ali SkZ, Grover M, Reddy G, Venkateswarlu B. Alleviation of drought stress effects in sunflower seedlings by the exopolysaccharides producing Pseudomonas putida strain GAP-P45. Biol. Fertil. Soils, 2009; 46: 17-26. https://doi.org/10.1007/s00374-0090401-z

92. Pawar ST, Bhosale AA, GawadeTB, Nale TR. Isolation, screening and optimization of exo-polysaccharide producing bacterium from saline soil. J. Microbiol. Biotechnol. Res., 2016; 3(3): 24-31.

93. Naseem $\mathrm{H}$, Bano A. Role of plant growth-promoting rhizobacteria and their exopolysaccharide in drought tolerance of maize. J. Plant Interact. 2014; 9 ; 689-701. https://doi.org/10.1080/17429145.2014.902125

94. Naseem $H$, Ahsan M, Shahid MA, Khan N. Exopolysaccharides producing rhizobacteria and their role in plant growth and drought tolerance. J. Basic Microbiol., 2018; 58: 1009-1022. https://doi. org/10.1002/jobm.201800309

95. Alami Y, Champolivier L, Merrien A, Heulin T. The role of Rhizobium sp. rhizobacterium that produces exopolysaccharide in the aggregation of the rhizospherical soil of the sunflower: Effects on plant growth and resistance to hydric constraint. $O C L$ - Oleagineux Corps Gras Lipides, 2000; 6: 524-528.

96. Vardharajula S, Zulfikar Ali S, Grover M et al., Droughttolerant plant growth promoting Bacillus spp.: effect on growth, osmolytes, and antioxidant status of maize under drought stress. J. Plant Interact., 2011 ; 6: 1-14. https://doi.org/10.1080/17429145.2010.535178

97. Sandhya V, Ali SZ, Grover M et al. Effect of plant growth promoting Pseudomonas spp. on compatible solutes, antioxidant status and plant growth of maize under drought stress. Plant Growth Regul., 2010a; 62: 21-30. https://doi.org/10.1007/s10725-010-9479-4

98. Ghosh D, Gupta A \& Mohapatra S. A comparative analysis of exopolysaccharide and phytohormone secretions by four drought-tolerant rhizobacterial strains and their impact on osmotic-stress mitigation in Arabidopsis thaliana. World J. Microbiol. Biotechnol., 
2019; 35: 90. https://doi.org/10.1007/s11274-0192659-0

99. Mahmood S, Daurl, Al-Solaimani, Ahmad S, Madkour MH, Yasir M, Hirt H, Ali S, Ali Z. Plant growth promoting rhizobacteria and silicon synergistically enhance salinity tolerance of mung bean Front. Plant Sci., 2016; 7: 1-14. https://doi.org/10.3389/fpls.2016.00876

100. Paul MJ, Primavesi LF, Jhurreea D, Zhang Y. Trehalose metabolism and signalling. Annu. Rev. Plant Biol., 2008; 59: 417-441. https://doi.org/10.1146/annurev. arplant.59.032607.092945

101. Close TJ, Dehydrins emergence of a biochemical role of a family of plant dehydration proteins. Physiol. Planta., 1996; 97: 795-803. https://doi.org/10.1034/j.13993054.1996.970422.x

102. Rahmani HA et al. Effect of Pseudomonas fluorescens on proline and phytohormonal status of maize (Zea mays L.) under water deficit stress. Ann.Biol.Res., 2012; 1054-1062.

103. Gusain YS, Singh US, Sharma AK. Bacterial mediated amelioration of drought stress in drought tolerant and susceptible cultivars of rice (Oryza sativa L.). Afr. J. Biotechnol., 2015; 14 :764-773. https://doi. org/10.5897/AJB2015.14405

104. Shintu PV, Jayaram KM. Phosphate solubilising bacteria (Bacillus polymyxa)-An effective approach to mitigate drought in tomato (Lycopersicon esculentum Mill). Trop. Plant Res., 2015; 2: 17-2.

105. Sandhya V, Ali SZ, Venkateswarlu B et al. Effect of osmotic stress on plant growth promoting Pseudomonas spp. Arch Microbiol., 2010b; 192: 867-876. https://doi.org/10.1007/s00203-010-0613-5

106. Rodriguez SJ, Suarez R, Caballero MJ, Itturiaga G. Trehalose accumulation in Azospirillum brasilense improves drought tolerance and biomass in maize plants. FEMS Microbiol. Lett., 2009; 296: 52-59. https://doi.org/10.1111/j.1574-6968.2009.01614.x

107. Bano Q, Ilyas N, Bano A, Zafar N, Akram A, F. Ul Hassan F. Effect of Azospirillum inoculation on maize (Zea mays L.) under drought stress. Pak. J. Bot., 2013; 45: 13-20.

108. Garcia JE, Maroniche G, Creus $C$ et al. In vitro PGPR properties and osmotic tolerance of different Azospirillum native strains and their effects on growth of maize under drought stress. Microbiol Res., 2017; 202: 21-29. https://doi.org/10.1016/j. micres.2017.04.007

109. Gou W, Tian L, Ruan Z, Zheng P, Chen F, Zhang L, Cui Z, Zheng P, Li Z, Gao M, Shi W, Zhang L, Liu J, Hu J. Accumulation of choline and glycinebetaine and drought stress tolerance induced in maize (Zea mays) by three plant growth promoting rhizobacteria (PGPR) strains. Pak. J. Bot., 2015; 47: 581-586.

110. Zhang G, Sun Y, Sheng H, Li H, and Liu X. Effects of the inoculations using bacteria producing ACC deaminase on ethylene metabolism and growth of wheat grown under different soil water contents. Plant Physiol. Biochem., 2018; 125: 178-184. https:// doi.org/10.1016/j.plaphy.2018.02.005

111. Ansary HA, Rahmani MR, Ardakani F, Paknejad, D. Habibi, S. Mafakheri. Effect of Pseudomonas fluorescens on proline and phytohormonal status of maize (Zea mays L.) under water deficit stress. Annal.
Biol. Res., 2012; 3: 1054-1062.

112. Cassan F, Maiale S, Masciarelli O, Vidal A, Luna V, Ruiz O. Cadaverine production by Azospirillum brasilense and its possible role in plant growth promotion and osmotic stress mitigation, Eur. J. Soil Biol., 2009; 45: 12-19. https://doi.org/10.1016/j.ejsobi.2008.08.003

113. Suarez R, Wong A, Ramirez M. Barraza A, OrozcoMdel C, Cevallos MA, et al. Improvement of drought tolerance and grain yield in common bean by over expressing trehalose-6-phosphate synthase in rhizobia. Mol. Plant Microb.Interact., 2008; 21: 958-966. https://doi.org/10.1094/MPMI-21-7-0958

114. Sen S, Ghosh D, Mohapatra S. Modulation of polyamine biosynthesis in Arabidopsis thaliana by a drought mitigating Pseudomonas putida strain. Plant Physiol. Biochem., 2018; 129: 180-188. https://doi. org/10.1016/j.plaphy.2018.05.034

115. Ghosh D, Sen S, Mohapatra S. Drought-mitigating Pseudomonas putida gap-P45 modulates proline turnover and oxidative status in Arabidopsis thaliana under water stress. Ann. Microbiol., 2018; 68: 579594. https://doi.org/10.1007/s13213-018-1366-7

116. Halliwell. Reactive species and antioxidants: Redox biology is a fundamental theme of aerobic life. Plant Physiol., 2006; 141(2) : 312-322. https://doi. org/10.1104/pp.106.077073

117. Miller G, Susuki N, Ciftci-Yilmaz S, Mittler R. Reactive oxygen species homeostasis and signalling during drought and salinity stresses. Plant Cell Environ., 2010; 33: 453-467. https://doi.org/10.1111/j.13653040.2009.02041.x

118. Heidari M, Golpayegani A. Effects of water stress and inoculation with plant growth promoting rhizobacteria (PGPR) on antioxidant status and photosynthetic pigments in basil (Ocimum basilicum L.) J. Saudi Soci. Agri. Sci., 2011: 11: 57-61. https://doi.org/10.1016/j. jssas.2011.09.001

119. Li H, Guo Q, Jing Y. et al. Application of Streptomyces pactum Act12 enhances drought resistance in wheat. J Plant Growth Regul., 2019; 1-11.

120. Gururani MA, Upadhyaya CP, Baskar V, Venkatesh J, Nookaraju A, Park SW. Plant growth-promoting rhizobacteria enhance abiotic stress tolerance in Solanum tuberosum through inducing changes in the expression of ROS scavenging enzymes and improved photosynthetic performance. J. Plant Growth Regul., 2013; 32: 245-258. https://doi.org/10.1007/s00344012-9292-6

121. Saravanakumar D, Kavino M, Raguchander T, Subbian P, Samiyappan R. Plant growth promoting bacteria enhance water stress resistance in green gram plants. Acta Physiol. Plant, 33: 203-209. https://doi. org/10.1007/s11738-010-0539-1

122. Wang CJ, Yang W, Wang C, Gu C, Niu DD, Liu HX, et al. Induction of drought tolerance in cucumber plants by a consortium of three plant growth-promoting rhizobacterium strains. PLoS One. 2012; 7:1-10. https://doi.org/10.1371/journal.pone.0052565

123. Sarma R, Saikia R. Alleviation of drought stress in mung bean by strain Pseudomonas aeruginosa GGRJ21. Plant Soil, 2014; 377: 111-126. https://doi.org/10.1007/ s11104-013-1981-9 
124. Kasim WA, Osman ME, Omar MN, Abd El-Daim IA, Bejai S, Meijer J. Control of drought stress in wheat using plant growth promoting bacteria. J. Plant Growth Regul., 2013; 32: 122-130. https://doi.org/10.1007/ s00344-012-9283-7

125. Wang $M$, Li P, Li C, Pan Y, Jiang X, Zhu D, Zhao Q, Yu JJ: SiLEA14, a novel atypical LEA protein, confers abiotic stress resistance in foxtail millet. BMC Plant Biol., 2014; 14: 290. https://doi.org/10.1186/s12870-014-0290-7

126. Joshi R, Wani SH, Singh B, Bohra A, Dar ZA, Lone AA, Pareek A, Singla SL. Transcription factors and plants response to drought stress: Current understanding and future directions. Front Plant Sci., 2016; 7: 1029. https://doi.org/10.3389/fpls.2016.01029

127. Shinozaki K, Yamaguchi-Shinozaki K. Gene networks involved in drought stress response and tolerance. J Exp Bot., 2007; 58: 221-227. https://doi.org/10.1093/ jxb/erl164

128. Kasual M. Microbes in cahoots with plants: MIST to hit the jackpot of agricultural productivity during drought. Int. J. Mol. Sci., 2019; 20(7): 1769. https:// doi.org/10.3390/ijms20071769

129. Wang D, Pan Y, Zhao X, Zhu L, Fu B, Li Z. Genome-wide temporal-spatial gene expression profiling of drought responsiveness in rice. BMC Genomics, 2011; 16(12): 149-164. https://doi.org/10.1186/1471-2164-12-149

130. Osakabe Y., Osakabe K., Shinozaki K., Tran L.S. P. Response of plants to water stress. Front. Plant Sci., 2014; 5: 86-93. https://doi.org/10.3389/ fpls.2014.00086

131. Nakashima K, Yamaguchi-Shinozaki K, Shinozaki K. The transcriptional regulatory network in the drought response and its crosstalk in abiotic stress responses including drought, cold, and heat. Front. Plant Sci., 2014; 5: 1-7. https://doi.org/10.3389/fpls.2014.00170

132. Kaur $\mathrm{G}$ and Asthir B. Molecular responses to drought stress in plants. Biol. Plant, 2017; 61: 201-209. https:// doi.org/10.1007/s10535-016-0700-9

133. Meena KK, Sorty AM, Bitla UM, Choudhary K, Gupta P, Pareek A, et al. Abiotic stress responses and microbemediated mitigation in plants: the omics strategies. Front. Plant Sci., 2017; 8: 172-194. https://doi. org/10.3389/fpls.2017.00172

134. Paterson J, Jahanshah G, Li Y, Wang Q, Mehnaz S, Gross $\mathrm{H}$. The contribution of genome mining strategies to the understanding of active principles of PGPR strains. FEMS Microbiol Ecol., 2017; 93: 1-31. https://doi. org/10.1093/femsec/fiw249

135. Kandasamy S, Loganathan K, Muthuraj R, et al.
Understanding the molecular basis of plant growth promotional effect of Pseudomonas fluorescens on rice through protein profiling. Proteome Sci., 2009; 7: 47-55. https://doi.org/10.1186/1477-5956-7-47

136. Vargas $L$, Santa Brigida $A B$, Mota Filho, JP, de Carvalha TG, Rojas CA, et al. Drought tolerance conferred to sugarcane by association with Gluconacetobacter diazotrophicus: A transcriptomic view of hormone, Plos One, 2014; 9(12): e114744. https://doi.org/10.1371/ journal.pone.0114744

137. Cho SM, Beom R, Yong K, Yang, C. Oung, K. Heol. Transcriptome analysis of induced systemic drought tolerance elicited by Pseudomonas chlororaphis 06 in Arabidopsis thaliana. Plant Pathol. J., 2013; 29: 209-220. https://doi.org/10.5423/PPJ.SI.07.2012.0103

138. Bakhsh A, Hussain T. Engineering crop plants against abiotic stress: current achievements and prospects. Emirates J Food Agri., 2015; 27: 24-39. https://doi. org/10.9755/ejfa.v27i1.17980

139. Davies JP, Christensen CA. Developing transgenic agronomic traits for crops: targets, methods, and challenges. In: Kumar S., Barone P., Smith M. (eds) Transgenic Plants. Methods in Molecular Biology. 2019; 1864. Humana Press, New York, NY. https://doi. org/10.1007/978-1-4939-8778-8_22

140. Sammons B, Whitsel J, Stork LG, Reeves W, Horak $\mathrm{M}$. Characterization of drought-tolerant maize MON 87460 for use in environmental risk assessment. Crop Sci., 2014; 54: 719-729. https://doi.org/10.2135/ cropsci2013.07.0452

141. Castiglioni P, Warner D, Bensen RJ, Anstrom DC, Harrison J, Stoecker M, Abad M,Kumar G, Salvador S, D'Ordine R. Bacterial RNA chaperones confer abiotic stress tolerance in plants and improved grain yield in maize under water-limited conditions. Plant Physiol., 2008; 147: 446-455. https://doi.org/10.1104/ pp.108.118828

142. Deikman J, Petracek M, Heard JE. Drought tolerance through biotechnology: improving translation from the laboratory to farmers' fields. Curr. Opin. Biotechnol., 2012; 23: 243-250. https://doi.org/10.1016/j. copbio.2011.11.003

143. Phuong ND, Tuteja N, Nghia PT, Hoi PX. Identification and characterization of a stress-inducible gene. OsNLIIF enhancing drought tolerance in transgenic tobacco Curr. Sci., 2017; 109: 541-551.

144. Dessaux Y, Grandclement C, Faure D. Engineering the rhizosphere. Trends Plant Sci., 2016; 21: 266-278. https://doi.org/10.1016/j.tplants.2016.01.002 